\title{
Pain and spatial inclusion: evidence from Mandarin
}

\author{
Michelle LiU And Colin Klein (D)
}

\section{Pain in English}

English has at least two distinct ways to report on physical pain. There is a predicative locution: 'My back hurts'; 'My back is painful'. The surface grammar is that of attributing a state to a body part. There is also a locative locution: 'There is a pain in my back'; 'I have a pain in my back'. On the level of surface grammar, this locution postulates that there is a thing, a pain, which can be possessed by a subject, and asserts that it is spatially located within a body part where the location is usually signalled by the prepositional phrase 'in NP (noun phrase)'. 1

The predicative locution is relatively neutral on what pains actually are. The locative form, by contrast, seems more committal: it treats pains as things that can be quantified over and can have spatial locations. Focus on this locution has driven a number of philosophical debates.

Bodily theories of pain claim that pains are, in some important sense, things which are located in body parts. For example, many theories claim that pain experience (in part or in whole) represents bodily damage (Armstrong 1962, Cutter and Tye 2011, Bain 2013). Damage is also the sort of thing that is located in our bodies, which means that these kinds of representationalism have a straightforward way to account for the locative form of pain reports. Conversely, the locative form has been used in arguments against (e.g.) adverbial theories of pain, which have to treat the locative form as a paraphrase (see Tye 1984). Adverbial theories are thought of as not squaring well with our ordinary conception of pain. Appealing to the locative form, Tye notes (1984: 319): '[w] certainly speak as if pains are felt objects which are located in sundry parts of our bodies'.

More broadly, the debate about the locative form is relevant to debates about the perceptual status of pain itself (Hyman 2003, Aydede 2005, Bain 2007). The locative form, at least on the surface, would commit pains to being the objects of sensation, rather than just properties of objects like body parts. Aydede (2013) uses numerous examples of the locative form to suggest that something in our ordinary conception favours an understanding of

1 In English, we can also appeal to experiential predicates like 'feel' and 'experience' to talk about pain: 'I feel pain'. In this case, the surface grammar appears to attribute a state to the subject of the experience, while sentences like 'I feel a pain in my leg' have features of the locative locution. However, as Fischer et al. (2015) emphasize, 'feels' talk can introduce additional implicatures; we thus focus on locutions which avoid the phrase. 
pains as if they were the objects of our perception'. And indeed, the following two sentences seem to be at least syntactically parallel:

I feel a pain in my leg.

I see a tree in the garden.

Whether this is in conflict with transparency theses that motivate intentionalism remains a contested question (see Aydede 2019 for a recent overview and argument).

Conversely, the locative form has raised persistent puzzles. Consider the following inference, from Block 1983: 517:

The pain is in my fingertip.

The fingertip is in my mouth.

Therefore, the pain is in my mouth.

Something has gone wrong. Block himself suggests that the 'in' of pain must signify something other than spatial enclosure. Noordhof (2001, 2002) agrees, noting numerous parallel cases of non-spatial 'in'. Tye disagrees, noting that there are multiple spatial uses of 'in' (2002) and that some of these uses set up intensional contexts where substitution fails (2005). Bain (2007) argues that there is no straightforward route from problematic arguments like Block's to a denial of an underlying metaphysical view on which pains are located. By contrast, Hyman (2003) and Noordhof (2005) both suggest that the puzzle can be solved by translating the locative form without remainder into the predicative, which in turn undermines the philosophical significance of the locative locution. More recently, Reuter et al. (2019) appeal to pragmatic implicatures to explain the puzzle, and give empirical evidence that these implicatures are cancellable. They take this to support a bodily view of pain.

In each case, while nominally about pain, the debate has turned on the interpretation of various English-language pain reports. Many English prepositions, including the preposition 'in', are opaque and overloaded with meaning, raising the possibility that these puzzles are an artefact of English grammar.

Cross-linguistic research has the potential to show which features of pain are artefacts of the English language, and which are universal and might in turn be taken to be philosophically significant (Wierzbicka 2012). Mandarin Chinese is the world's most widely spoken native tongue (Wang and Sun 2015: 578), and so makes an excellent test case.

\section{Pain in Mandarin}

The English word 'pain' is translated into Mandarin as either tòng (痛) or téngtòng (疼痛). The former is used either as a noun or as a verb, whereas the 
latter is used only as a noun. There is also the word téng (疼), which is predominantly used as a verb. Mandarin speakers from northern China tend to use the word téng (疼), whereas those from southern China tend to use the word tòng (痛).

At a first pass, the standard way to discuss pain in Mandarin closely parallels the predicative locution in English: ${ }^{2}$

我背疼

Wŏ bèi téng

1SG back hurt

'My back hurts.'

我的背很痛

wŏ de bèi hěn tòng

1SG LIG back very ache

'My back is very sore.'

我背不舒服

wŏ bèi bù shūfú

1SG back not comfortable

'My back is not comfortable'3

On the other hand, there appears to be no straightforward equivalent of the locative form. Indeed, it would seem that pain reports in Mandarin cannot have many of the features of the locative form.

The locative form for reporting on physical pain in English has the following four features:

2 1SG: first person singular; CL: classifier; LIG: marker of ligature in dependency relations.

3 Mandarin also has a way to discuss pain that closely parallels the English locution 'I feel pain':

我感觉痛
wǒ gănjué tòng
1SG feel ache
'I feel pain.'
我感觉背痛
wǒ gănjué bèi tòng
1SG feel back ache
'I feel that my back aches.'

However, one cannot directly render English sentences like 'I feel $a$ pain' or 'I feel pain in my back' in Mandarin. 
(1) It uses a prepositional phrase; most importantly, it can take the preposition 'in' as in 'in my back' - the use of the preposition 'in' signals the body part where pain is located;

(2) Pain is countable - one can say 'a pain';

(3) It permits an existential construction as in 'THERE IS a pain'.

(4) It permits a possessive construction as in 'I HAVE a pain in my back'. ${ }^{4}$

The surface grammar of the locative locution suggests that pain is analogous to physical objects whose location in space can be specified with the prepositional phrase 'in NP'. Pains are also treated as countable objects. We can use the existential construction, for example 'There is a pen', and the possessive construction, for example 'I have books', to talk about physical objects; it appears that parallel talk about pain is also licensed.

All four features of the locative locution of pain attribution that are present in English are impermissible in Mandarin. Indeed, corresponding sentences with the same surface grammar are not just odd but (in most cases) flatly ungrammatical:

(1) Mandarin does not have a similar construction to the prepositional phrase 'in NP' in English to report the location of pain. The location of pain is usually specified by the noun phrase in the predicative locution which also acts as the subject of the sentence:

\section{我的肚子疼}

Wǒ de dùzi téng

1SG LIG stomach hurt

'My stomach hurts.'

However, Mandarin does use the postposition li, similar in meaning to the English prepositions 'in' or 'inside', in specifying the location of concrete physical objects:

我包里有一本

wǒ bāo-li yǒu yīběn shū

1SG bag-in there.is one:CL book

'There is a book in my bag.' 'there is', or possession, 'have'. The difference is traced to a difference in the relevant syntactic properties: 'The "have" use of yǒ $u$ takes two arguments in a relational type of clause (POSSESSOR-NP yǒ $и$ POSSESSED-NP), whereas existential yǒ typically postverbal, argument' (Chappell 2002: 285). 
In colloquial Mandarin, $l \grave{l}$ is sometimes used in the particular phrase $x \bar{i} n$-li tòng to mean that one is in emotional pain (though it is more common to leave out the word $(\bar{l})$ :

我心里痛

wǒ xīn-li tòng

1SG heart-in ache

'My heart aches.'

Nevertheless, $l \grave{l}$ is not usually used in a postpositional phrase in Mandarin to signal the body part affected by physical pain.

(2) In Mandarin, pain is not countable. One cannot say 'a pain':

*一个疼痛

"yīgè téngtòng

one:CL pain

'a pain'

In contrast, one can say 'a wound':

一个伤口

yīgè shāngkǒu

one:CL wound

'a wound'

In Mandarin, sensations in general are not countable, whereas things like wounds are. While English permits phrases such as 'an itch', 'a tickle' etc., direct renderings of these phrases are ungrammatical in Mandarin.

(3) While Mandarin has an equivalent to 'there is' in English (i.e. yǒu), it seems that such a construction cannot be used in the context of reporting sensations and their locations. Mandarin does not permit this existential construction with respect to pain:

"我耳朵后面有痛

*wǒ ěrduo hòumiàn yǒu tòng

1SG ear behind there.is ache

'There is an ache behind my ear.'

In contrast, the existential construction can be used in Mandarin with respect to concrete physical objects:

我包里有笔

wǒ bāo-li yǒu bř 
1SG bag-in there.is pen

'There is a pen in my bag. / There are pens in my bag.'

(4) Mandarin does not permit the possessive construction with respect to pain:

*我有痛

"wǒ yǒu tòng

1SG have pain

'I have pain.'

In contrast, the possessive construction can be used in Mandarin with respect to concrete physical objects:

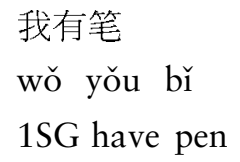

'I have a pen. / I have pens.'

The locative use of pain reports is defined by the four features outlined above: (1) 'pain' can take the prepositional phrase 'in NP'; (2) 'pain' is countable; (3) 'pain' can take the existential construction 'There is NP'; (4) 'pain' can take the possessive construction 'NP have NP'. Given that all these four features are impermissible or absent in Mandarin, it is reasonable to conclude that Mandarin does not have the locative locution for reporting on physical pain that is employed by English.

\section{More complex cases}

Mandarin is a complex language, and some locutions are more difficult to analyse. However, closer examination reveals that none support a locative reading.

First, Mandarin does use postpositional phrases to indicate the location of pain. For instance, one can say:

我的眼睛后面疼

wǒ de yănjīng hòumiàn téng

1SG LIG eye behind hurt

'Behind my eye hurts.'

However, closer inspection reveals that postpositions are primarily used when the pained body part has no name in the language. Thus understood, 
the locution is still predicative, with the location information serving to pick out an otherwise un-named body part of which hurting is predicated.

Second, the following phrase in Mandarin might appear to suggest that pain is countable:

一阵痛

yīzhèn tòng

a.short.period pain

'pain that is sudden and lasts for a short period'

The word yizhèn seems to be a fixed phrase, referring to a short duration. The word zhèn as used in 'yizzhèn tòng' should not be treated as a classifier. For instance, it sounds odd to say:

$$
\begin{aligned}
& \text { *两阵痛 } \\
& \text { "liăng zhèn tòng } \\
& \text { two short.period pain } \\
& \text { 'two (sudden, short) pains' }
\end{aligned}
$$

So, even if Mandarin has the phrase yizzhèn tòng, it does not mean that pain is countable or is treated as something that is quantifiable. Furthermore, the phrase yizhèn seems to be a fixed phrase that functions like an adverb in the following construction:

我肚子一阵痛

wǒ dùzi yīzhèn tòng

1SG stomach a.short.period pain

'My stomach hurt suddenly and for a short period. ${ }^{5}$

Third, Mandarin does have the following locution which can appear to be an instance of the possessive construction where pain seems to be quantifiable:

我有点痛

wǒ yǒudiăn tòng

1SG a.bit hurt

'I hurt a bit.'

5 We acknowledge that this grammatical analysis of yizzhèn tòng (一阵痛) is somewhat contentious. An anonymous reviewer has suggested that the word zhèn (阵) in yizhèn is a meaningful item and should be taken as a measure word rather than an individual classifier like gè (个). We have argued that yizzhèn as used in 'yizzhèn tòng' is a fixed phrase and zhèn in this context should not be treated as a classifier of any sort. But even on this alternative analysis of yizhèn tòng, pain is uncountable in Mandarin as nouns for 'pain', namely, téngtòng and tòng, can only be combined with measure words. 
However, the phrase yǒudiăn (有点) in this context functions as an adverb. This adverb can also be used to describe the intensities of sensations and emotions in general.

The phrase yǒudiăn (有点) sometimes gets treated as the conjunction of a verb, yǒu, plus a quantifier, diăn, to mean either 'have a bit of' or 'there is a bit (of something)'. For instance, one can say the following:

锅里有点米饭

guō-li yǒu diăn mǐfàn

pot-in there.is a.bit rice

'There is a bit of rice in the pot.'

Equally, one can say 'There is a lot of rice' with the phrase 'yǒu quantifier', yǒu běnduō in this case. In the case of describing the intensity of pain, yǒndiăn is a fixed phrase that functions as an adverb to modify the verb tòng. One cannot say the following:

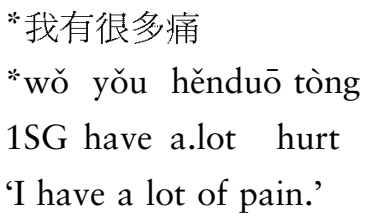

The above utterance is ungrammatical because Mandarin does not permit the possessive construction 'NP yǒ general. One can of course convey the meaning of 'I have a lot of pain' in Mandarin with the predicative locution:

我很痛

wǒ hěn tòng

1SG very hurt

'I hurt a lot.'

In sum, although Mandarin has a variety of more complex locutions regarding pain, none give evidence for a locative reading of pain.

\section{Conclusion}

There is considerable evidence that Mandarin Chinese lacks anything like the locative use of pain. Assuming, plausibly, that the experience of physical pain itself is a cross-cultural universal, this suggests that the surface grammar of the locative form is philosophically misleading and should not be relied upon to support philosophical theses.

What is the philosophical upshot of this result? Most at risk, we believe, are bodily views of pain which identify pains with bodily states such as tissue 
damage (Massin 2017, Reuter et al. 2019). Also at risk are versions of representationalism on which pains are objects located in the body - for example, because pain experiences in fact represent tissue damage (Cutter 2017). Note that there is something of an ambiguity here in the way that representationalist views are presented. As Tye (2005: 101) notes,

The term 'pain,' in one usage, applies to the experience; in another, it applies to the quality represented insofar as (and only insofar as) it is within the content of a pain experience.

Insofar as the represented content is cashed out as a located bodily quality, representationalism is threatened.

Conversely, representationalist views on which the represented object is the body, or a relationship between a subject and their body (as in Noordhof 2005) should be unaffected. These stick more closely to the predicative locution in English, which is directly paralleled in Mandarin. Similarly, imperative views such as Klein's (2015), on which the location of the pain is fundamentally determined by the pained body part, should be unaffected.

Furthermore, as we have noted, not only does Mandarin lack the 'in NP' construction to talk about pain, features (2)-(4), which treat pain as a countable object over which one can quantify, are equally poorly supported in Mandarin. As a result, this may well have broader consequences for the debate over perceptual theories of pain.

This may re-open the door to pure predicative or adverbial theories of pain. These have been criticized precisely because they appear to be in conflict with the locative form of pain expressions in English (Tye 1984). If those expressions are language-specific, however, such constraints are less strong than they might appear.

Our discussion also invites further empirical investigations into cross-cultural and cross-linguistic differences in people's conceptions of pain. A deflationary reading of the above would suggest that the puzzles about pain are due to quirks of the surface grammar of English; these quirks have misled Englishspeaking philosophers about the universal concept of pain. A more cautious reading might suggest that the linguistic differences represent differences in the concept of pain among different populations; there is independent experimental evidence that English speakers have a bodily conception of pain (Reuter and Sytsma forthcoming). Adjudicating between the two possibilities requires further empirical research, some of which has already begun (Kim et al. 2017).

Either way, our analysis is an example of how cross-linguistic work may help sharpen and clarify philosophical disputes which have been conducted largely in a single Indo-European language. ${ }^{6}$ Here, we note that our argument

6 In that sense it is in the tradition of Machery et al. 2004. However, we note that crosscultural experimental philosophy has itself been criticized for lack of attention to linguistic differences (Lam 2010). 
does not rely on the claim that the locative locutions for pain in English are untranslatable into Mandarin. ${ }^{7}$ Nor do we intend to advance dubious claims about differences in pain experience between English and Mandarin speakers. The point is instead meta-philosophical. Much of the literature on pain has focused on the specific grammatical features that are associated with the locative form of pain reports in English. The fact that these features do not and cannot occur in Mandarin should cast serious doubt upon that strategy.

Careful discussion of English locutions has an important place in analytic philosophy, of course. We do not wish to disparage such work. Yet crosslinguistic evidence can be an important check to make sure that we are focusing on features of the world, rather than artefacts of our native tongue. ${ }^{8}$

\section{Funding}

This study was supported by ARC grant FT140100422 (to C.K.) and an ANU exchange travel grant provided by the University of Oxford (to M.L.).

University of Oxford

Oxford OX2 6GG, UK michelle.liu@some.ox.ac.uk

The Australian National University

Canberra ACT 0200, Australia colin.klein@anu.edu.au

\section{References}

Armstrong, D. 1962. Bodily Sensations. New York: Routledge \& Kegan Paul.

Aydede, M. 2005. The main difficulty with pain. In his Pain: New Essays on the Nature of Pain and the Methodology of Its Study, 123-36. Cambridge: MIT Press.

Aydede, M. 2013. Pain. In The Stanford Encyclopedia of Philosophy, Spring 2013 edn., ed. E.N. Zalta. Stanford University. <https://plato.stanford.edu/archives/spr2013/ entries/pain/>.

Aydede, M. 2019. Is the experience of pain transparent? Introspecting phenomenal qualities. Synthese 196: 677-708.

Bain, D. 2007. The location of pains. Philosophical Papers 36: 171-205.

7 Trivially so. Locative locutions for pain in English are translatable into Mandarin. However, the translated sentences would usually have a surface grammar parallel to that of the predicative locution in English, for example 'My back hurts'. So the translated sentences would not have the surface grammar parallel to that of the locative locution of English.

8 We would like to thank three referees for their valuable comments. Thanks also to Zhengdao Ye and Jiahe Zhang for helpful discussions on pain discourse in Mandarin, and to Peter Clutton, Esther Klein and Ross Pain for helpful comments on a previous draft. 
Bain, D. 2013. What makes pains unpleasant? Philosophical Studies 166: 69-89.

Block, N. 1983. Mental pictures and cognitive science. Philosophical Review 92: 499_ 541.

Chappell, H. 2002. The universal syntax of semantic primes in Mandarin Chinese. In Meaning and Universal Grammar: Theory and Empirical Findings, vol. 1, eds. C. Goddard and A. Wierzbicka, 243-322. Amsterdam: John Benjamins.

Cutter, B. 2017. Pain and representation. In The Routledge Handbook of Philosophy of Pain, ed. J. Corns, 29-39. New York: Routledge.

Cutter, B. and M. Tye. 2011. Tracking representationalism and the painfulness of pain. Philosophical Issues 21: 90-109.

Fischer, E., P.E. Engelhardt and A. Herbelot. 2015. Intuitions and illusions: from explanation and experiment to assessment. In Experimental Philosophy, Rationalism, and Naturalism: Rethinking Philosophical Method, eds. E. Fischer and J. Collins, 259-92. New York: Routledge.

Hyman, J. 2003. Pains and places. Philosophy 78: 5-24.

Kim, H., N. Poth, K. Reuter and J. Sytsma. 2017. Where is your pain? A cross-cultural comparison of the concept of pain in Americans and South Koreans. Studia Philosophica Estonica 9: 136-69.

Klein, C. 2015. What the Body Commands: The Imperative Theory of Pain. Cambridge: MIT Press.

Lam, B. 2010. Are Cantonese-speakers really descriptivists? Revisiting cross-cultural semantics. Cognition 115: 320-9.

Machery, E., R. Mallon, S. Nichols and S.P. Stich. 2004. Semantics, cross-cultural style. Cognition 92: B1-12.

Massin, O. 2017. Bad by nature: an axiological theory of pain. In The Routledge Handbook of Philosophy of Pain, ed. J. Corns, 321-33. New York: Routledge.

Noordhof, P. 2001. In pain. Analysis 61: 95-7.

Noordhof, P. 2002. More in pain. Analysis 62: 153-4.

Noordhof, P. 2005. In a state of pain. In Pain: New Essays on the Nature of Pain and the Methodology of Its Study, ed. M. Aydede, 151-62. Cambridge: MIT Press.

Reuter, K. and J. Sytsma. forthcoming. Unfelt pains. Synthese.

Reuter, K., M. Sienhold and J. Sytsma. 2019. Putting pain in its proper place. Analysis 79: $72-82$.

Tye, M. 1984. Pain and the adverbial theory. American Philosophical Quarterly 21: 319-27.

Tye, M. 2002. On the location of a pain. Analysis 62: 150-3.

Tye, M. 2005. Another look at representationalism about pain. In Pain: New Essays on the Nature of Pain and the Methodology of Its Study, ed. M. Aydede, 99-120. Cambridge: MIT Press.

Wang, W.S. and C. Sun. 2015. The Oxford Handbook of Chinese Linguistics. Oxford: Oxford University Press.

Wierzbicka, A. 2012. Is pain a human universal? A cross-linguistic and cross-cultural perspective on pain. Emotion Review 4: 307-17. 